\title{
Sistem Informasi Penjualan Bibit Tanaman di Toko Higar Agro Berbasis Android
}

\author{
Paryanta $^{* 1}$, Haryo Basuki ${ }^{2}$, Agung Widhiyatmoko ${ }^{3}$ \\ ${ }^{1}$ Program Studi Teknik Komputer, STMIK AUB, Surakarta, Indonesia \\ ${ }^{2}$ Program Studi Sistem Komputer, STMIK AUB, Surakarta, Indonesia \\ ${ }^{3}$ Program Studi Sistem Informasi, STMIK AUB, Surakarta, Indonesia \\ e-mail: *11paryanta@stmik-aub.ac.id, ${ }^{2}$ haryo.basuki@stmik-aub.ac.id, \\ 32167100852@student.stmik-aub.ac.id
}

\begin{abstract}
Abstrak
Higar agro adalah sebuah toko yang khususnya bergerak dalam bidang penjualan pertanian, Semakin meningkatnya perkembangan toko bibit Higar agro sekarang ini telah menjadi toko pertanian yang sangat berkembang, mencatat lebih dari ribuan transaksi penjualan dalam setiap tahunnya sehingga menuntut pihak perusahaan untuk dapat menyediakan layanan pemesanan bagi konsumen guna menunjang transaksi penjualan dan pelayanan lebih baik. Metode pengembangan sistem yang digunakan dalam pengembangan sistem adalah metode watefall yang digunakan untuk menggambarkan model sistem adalah berupa flowchart, Unified Modelling Language (UML), Class Diagram, Activity Diagram dan Squence diagram serta dalam perancangan basis data menggunakan PhpMyadmin. Untuk mengimplementasikan sistem informasi penjualan dan pemesanan ini, dibutuhkan komponen pendukung agar dapat bekerja dengan baik. Komponen tersebut diantaranya menggunakan bahasa pemrograman PHP, Android dan Java, untuk penyimpanan data menggunakan database MySQL. Perancangan sistem ini diharapakan bisa membantu dan mengatasi permasalahan yang ada sehingga dapat bermanfaat bagi pihak-pihak yang berkepentingan.
\end{abstract}

Kata kunci- Sistem Informasi Penjualan Bibit Tanaman, Penjualan Bibit Tanaman, Android,Android Studio, Higar Agro

\begin{abstract}
Higar agro is a shop that is primarily engaged in agricultural sales, the increasing development of Higar agro seed shops has now become a very developed agricultural shop, recording more than thousands of sales transactions each year, thus requiring the company to be able to provide ordering services for consumers in order to support sales transactions and better service. The system development method used in system development is the watefall method which is used to describe the system model in the form of flowcharts, Unified Modeling Language (UML), Class Diagrams, Activity Diagrams and Squence diagrams and in database design using PhpMyadmin. To implement this sales and ordering information system, support components are needed in order to work properly. These components include using the programming language PHP, Android and Java, for data storage using the MySQL database. It is hoped that the design of this system can help and overcome existing problems so that it can be of benefit to the parties concerned.
\end{abstract}

Keywords—Plant Seed Sales Information System, Sales of Plant Seeds, Android, Higar agro 


\section{PENDAHULUAN}

Teknologi internet mempunyai efek yang sangat besar pada perdagangan dan juga bisnis. Saat ini kebanyakan orang mengakses internet menggunakan smartphone. Salah satu smartphone yang beredar luas di pasaran adalah smartphone berbasis android. Kelebihan dari sistem operasi Android adalah mudah dalam pengoperasiannya sehingga banyak pengguna aktif yang menggunakan android, selain itu aplikasi-aplikasi yang tersedia sangat beragam bahkan didukung oleh banyak developer. Perangkat android juga sangat mudah dibawa kemanapun sehingga inilah yang menjadi dasar utama mengapa android begitu pesat berkembang bahkan menurut Google I/O pada tahun 2019 ada 2,5 milyar perangkat aktif setiap bulannya.

Perkembangan teknologi yang pesat menjadikan banyak pebisnis yang mulai menjual bibit tanaman sehingga mengakibatkan banyaknya persaingan yang terjadi di bisnis penjualan bibit tanaman. Toko bibit tanaman Higar agro merupakan pusat penjualan bibit tanaman dan alat-alat pertanian yang melayani melalui online shop maupun toko fisik. Produk yang dijual adalah produk dengan kualitas tinggi yang dijamin varietas keaslian bibitnya. Higar agro juga memberikan garansi untuk varietas bibit dan garansi dalam pengiriman bibit tanaman. Berdiri sejak tahun 2014 toko bibit tanaman Higar agro sudah melakukan pengiriman bibit hingga seluruh Indonesia. Sudah lebih dari 100.000 bibit tanaman terjual baik melalui online maupun offline. Dampak dari wabah covid-19 yang mewajibkan karyawan WFH (Work From Home) membuat aktifitas masyarakat yang sangat terbatas sehingga bertani dan bercocok tanam menjadi pilihan sehat dan mudah bagi banyak orang sehingga penjualan produk pertanian meningkat sangat pesat.

Toko bibit tanaman Higar Agro memiliki beberapa permasalahan dalam pelayanan dan penjualan bibit tanaman serta kurangnya informasi toko di media sosial sehingga kurang adanya perkembangan pengiklanan bibit tanaman tersebut. Proses pengiklanan di toko bibit Higar Agro menggunakan facebook ads diarahkan ke market place sehingga memiliki jangkauan sangat luas namun terkendala banyaknya persaingan membuat iklan yang dihasilkan kurang tepat sasaran. Proses transaksi di toko bibit tanaman Higar Agro secara online masih menggunakan bantuan toko online seperti Tokopedia, Shopee dan Bukalapak sehingga banyak calon pelanggan yang tidak jadi melakukan transaksi pembelian karena banyaknya persaingan harga yang terjadi di toko online tersebut, selain itu dalam segi proses pengolahan data dan transaksinya, pada toko bibit tanaman Higar Agro masih dilakukan secara manual, misalnya pelanggan yang datang langsung datang di kebun masih dicatat secara manual dalam Microsoft excel, sehingga sangat tidak baik dalam hal pemeliharaan data dan sangat rentan terjadi sebuah kesalahan atau kecurangan dalam pembuatan laporan dan pemberian informasi.

Melihat masalah yang terdapat di toko Higar Agro, maka mendorong penulis untuk membuat sebuah sistem informasi penjualan Higar Agro dan dalam penyusunan skripsi ini penulis mengambil judul "Sistem Informasi Penjualan Bibit Tanaman di Toko Higar Agro Berbasis Android".

\section{METODE PENELITIAN}

\subsection{Pengumpulan Data}

a. Wawancara

Wawancara merupakan metode pengumpulan data yang menghendaki komunikasi langsung antara penyelidik dengan responden (Riyanto, 2010). Penulis melakukan wawancara dengan pemilik toko Higar Agro bagaimana sistem yang sedang berjalan di toko Higar Agro.

b. Observasi

Dalam observasi peneliti terlibat dengan kegiatan sehari-hari orang yang sedang diamati atau yang digunakan sebagai sumber data penelitian (Siyoto, Sandu dan sodik, Ali, 2015). 
Penulis melakukan observasi dengan mengamati secara langsung proses penjualan bibit tanaman di Toko Higar Agro.

c. Metode Pustaka

Studi kepustakaan berkaitan dengan kajian teoritis dan referensi lain yang terkait dengan nilai, budaya, dan norma yang berkembang pada situasi sosial yang diteliti. Dan ada tiga kriteria yang terkait teori yang digunakan sebagai landasan penelitian, yaitu relevansi, kemutakhiran dan keaslian (Siyoto, Sandu dan sodik, Ali, 2015). Penulis mencari informasi dari internet, dari perpustakaan, dari buku dan jurnal sebagai bahan referensi sebagai acuan dalam penulisan laporan dan juga pembuatan software aplikasi ini.

\subsection{Use Case Diagram}

Use Case mendiskripsikan sebuah interaksi antara lebih aktor dengan sistem informasi yang akan dibuat. Use case aksi antar aktor yang meliputi pembeli dan penjual. Untuk lebih jelasnya seperti gambar 1.

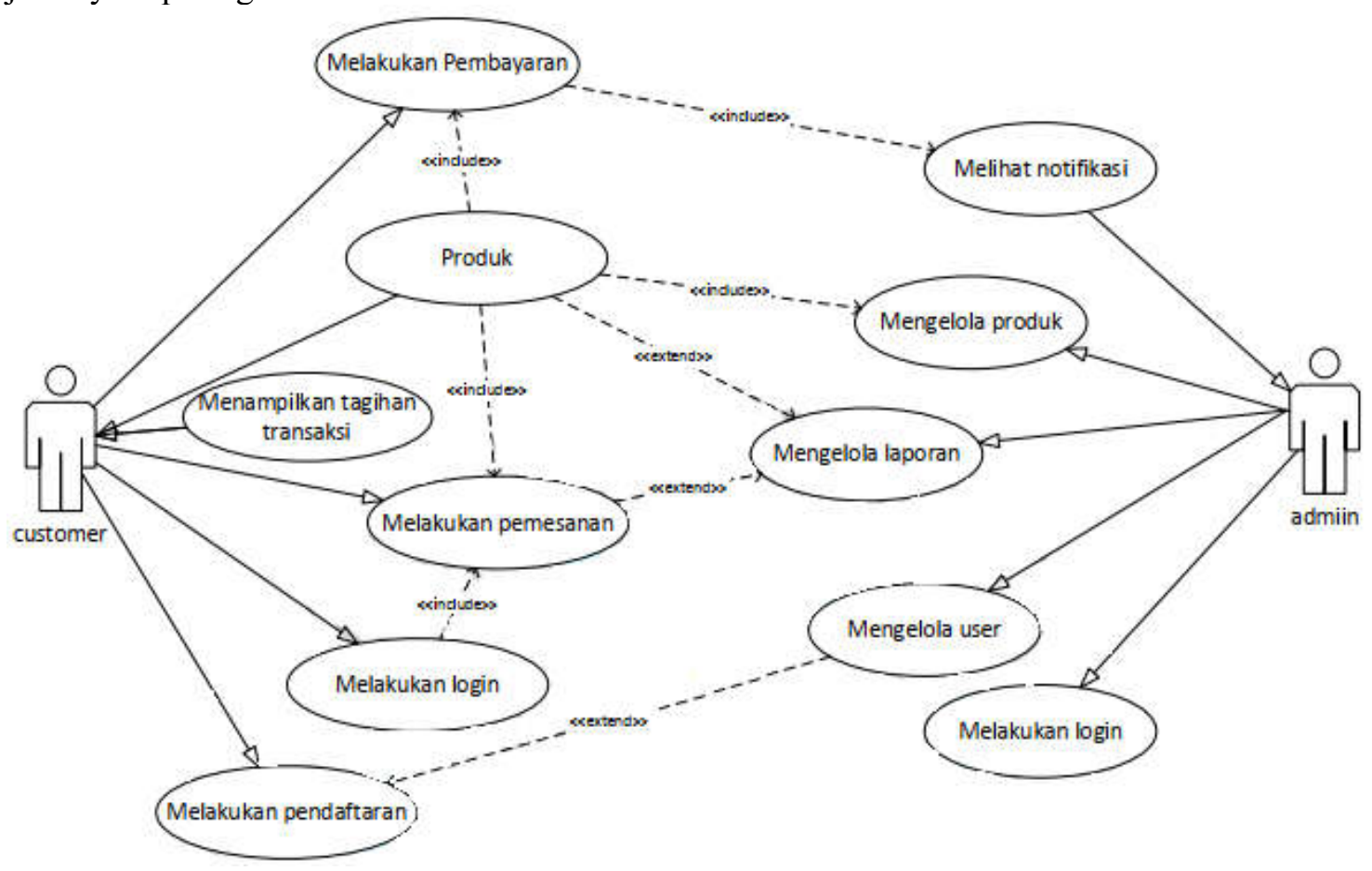

Gambar 1. Use Case Diagram

\section{HASIL DAN PEMBAHASAN}

\subsection{Implementasi Sistem}

Dalam pembuatan aplikasi ini dibutuhkan suatu implementasi untuk menguraikan program dan analisis dari hasil program yang telah dibuat. Tujuan pembahasan ini adalah untuk mengetahui apakah program yang dibuat sudah bekerja seperti yang diharapkan atau belum. Berikut adalah proses pembahasan interface atau antarmuka program: 


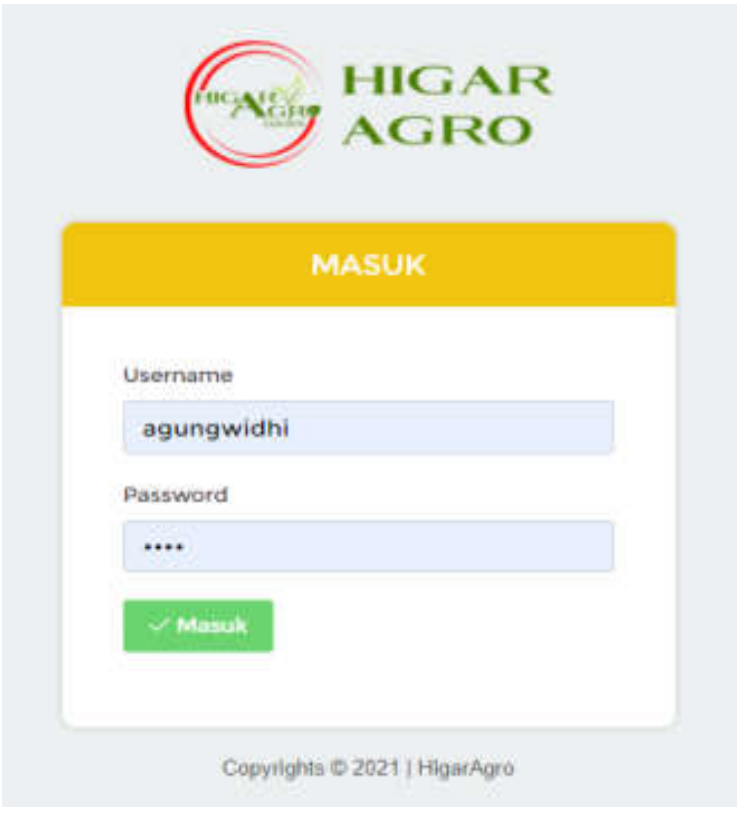

Gambar 2. Halaman Login Admin

Gambar 2. Halaman login admin digunakan oleh admin untuk masuk kedalam halaman admin. Admin harus memasukkan username dan password yang sudah terdaftar. Klik "Masuk" untuk masuk ke halaman utama admin.

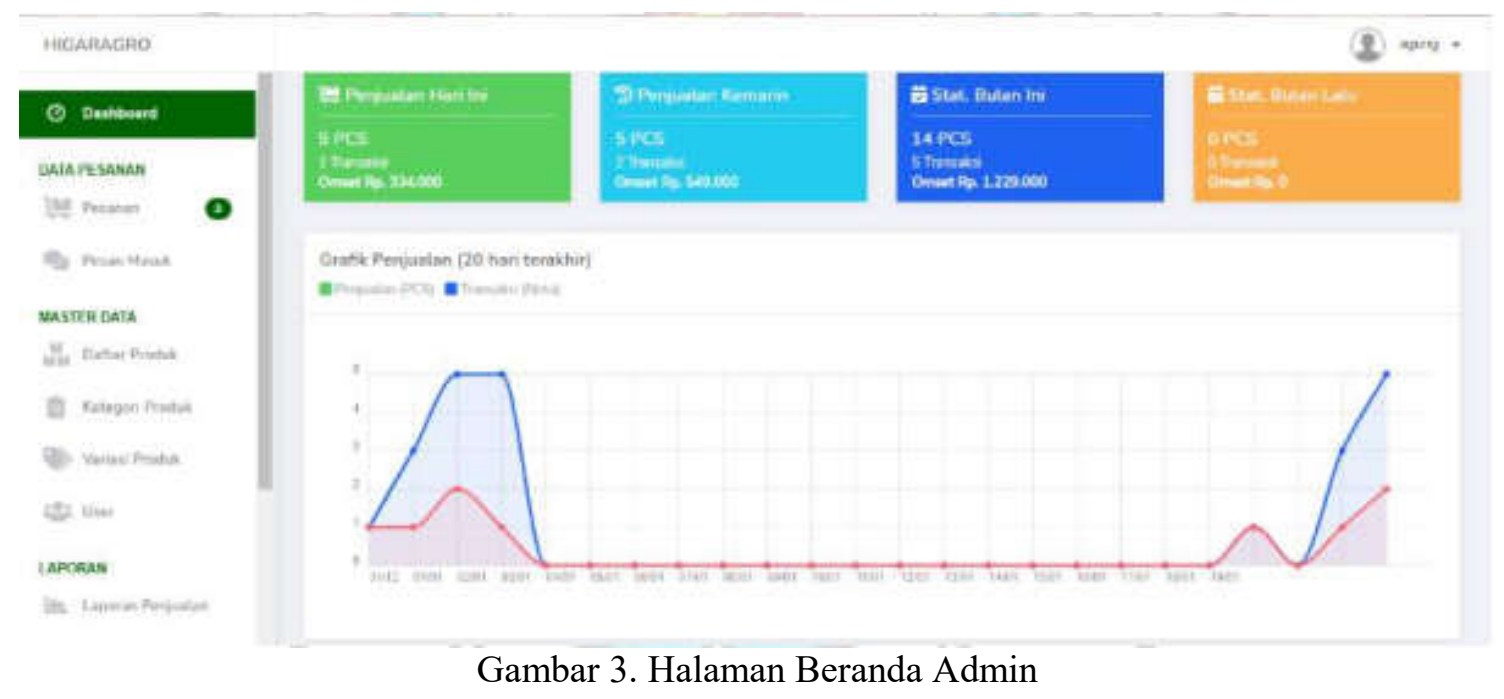

Gambar 3 Halaman utama admin, menampilkan halaman awal ketika admin berhasil login kedalam sistem. Pada halaman utama admin menampilkan pilihan menu pesanan, pesan masuk, daftar produk, kategori produk, variasi produk, user, laporan penjualan, pengaturan dan logout. Kemudian pada body halaman terdapat grafik penjualan produk. 


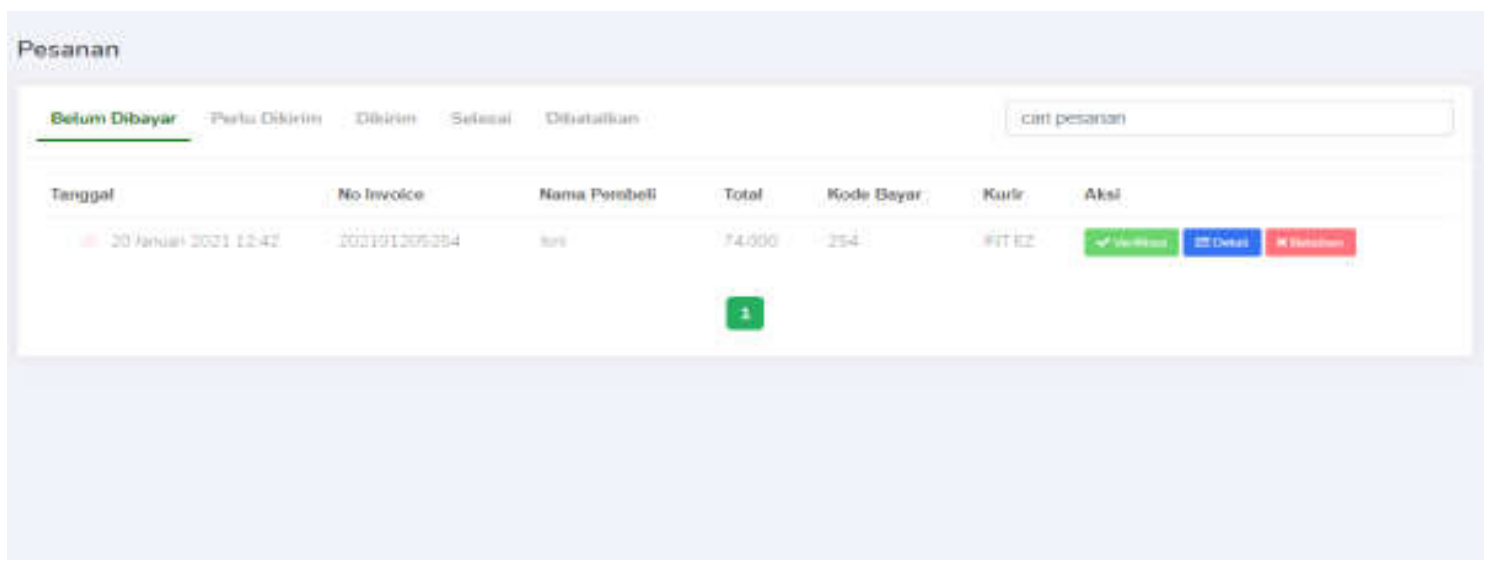

Gambar 4. Halaman Pesanan

Gambar 4 Klik menu pesanan pada halaman utama admin untuk masuk ke halaman pesanan. Halaman pesanan menampilkan daftar pesanan customer Higaragro. Pada tab Belum bayar menampilkan data tanggal pemesanan, nomer invoice, nama pembeli, total, kode bayar, kurir dan tombol aksi verifikasi, detail dan batalkan. Pada Tab perlu dikirim memiliki tambahan tombol label untuk mencetak label pengiriman dan resi untuk menginput resi pengiriman. Pada tab dikirim memiliki tambahan tombol update resi dan lacak kiriman.

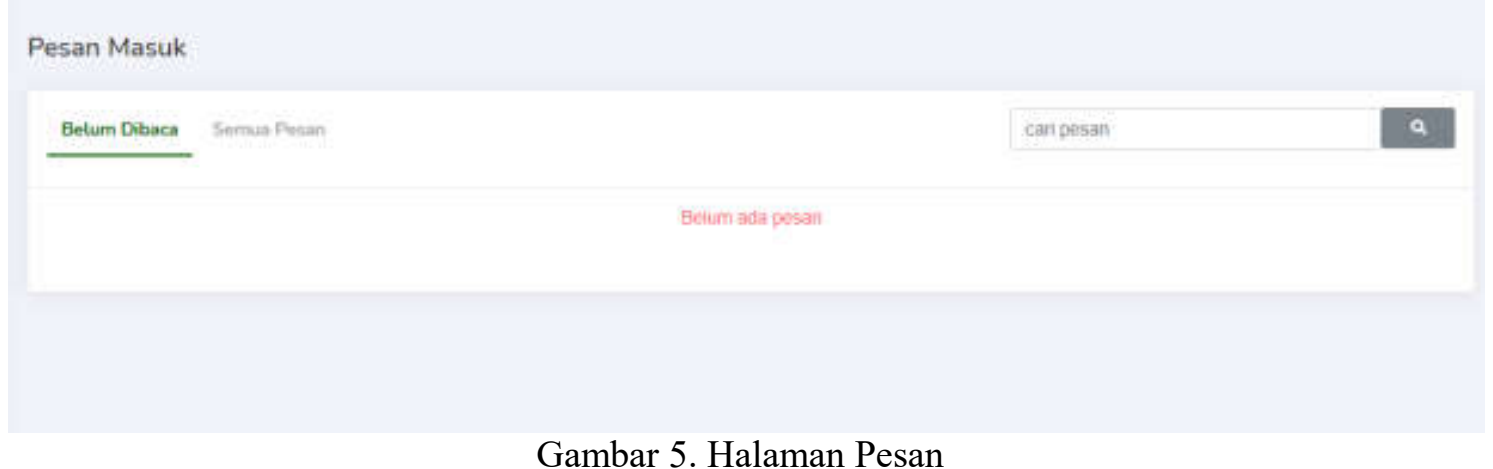

Gambar 5. Halaman Pesan

Gambar 5 Klik menu pesan pada halaman utama admin untuk masuk ke halaman pesan. Halaman pesan masuk menampilkan data pesan / chat dari pelanggan. Informasi yang ditampilkan yaitu pesan masuk dari pelanggan yang belum terbaca maupun yang sudah terbaca.

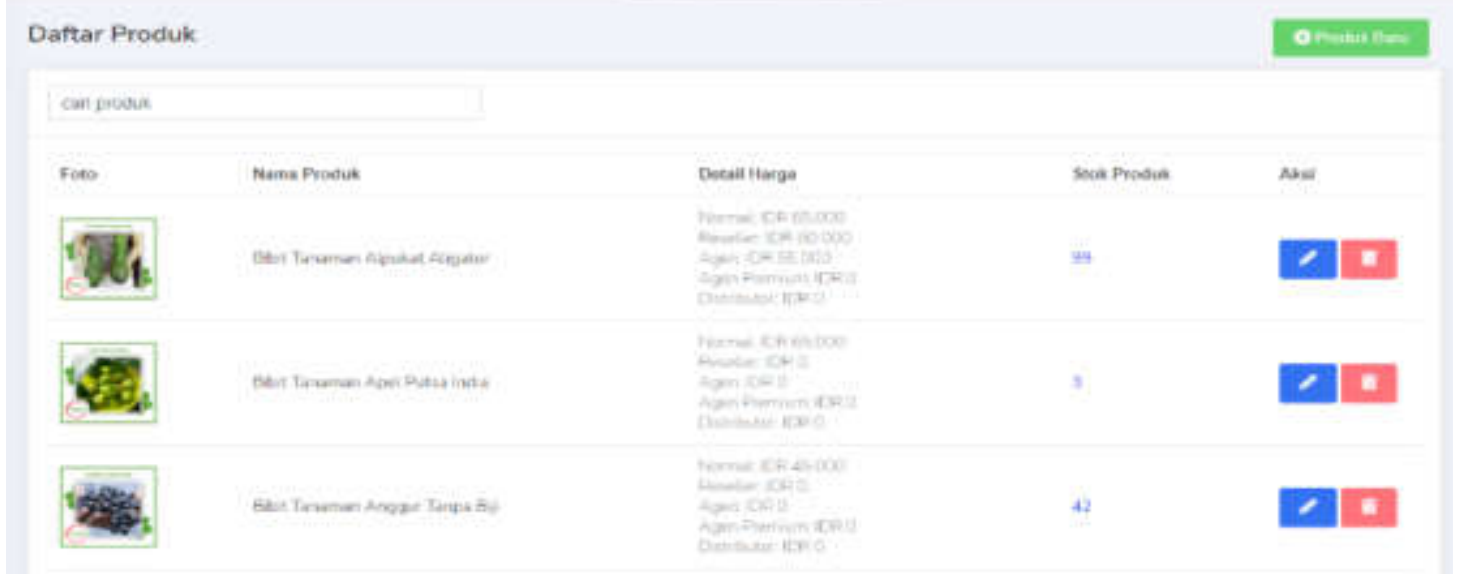

Gambar 6. Halaman Daftar Produk

Gambar 6 Klik menu produk pada halaman utama admin untuk masuk ke halaman produk. Halaman daftar produk menampilkan daftar produk yang tersedia di aplikasi pemesanan 
higaragro.com. Informasi yang ditampilkan yaitu foto produk, nama produk, detail harga dan stok produk.

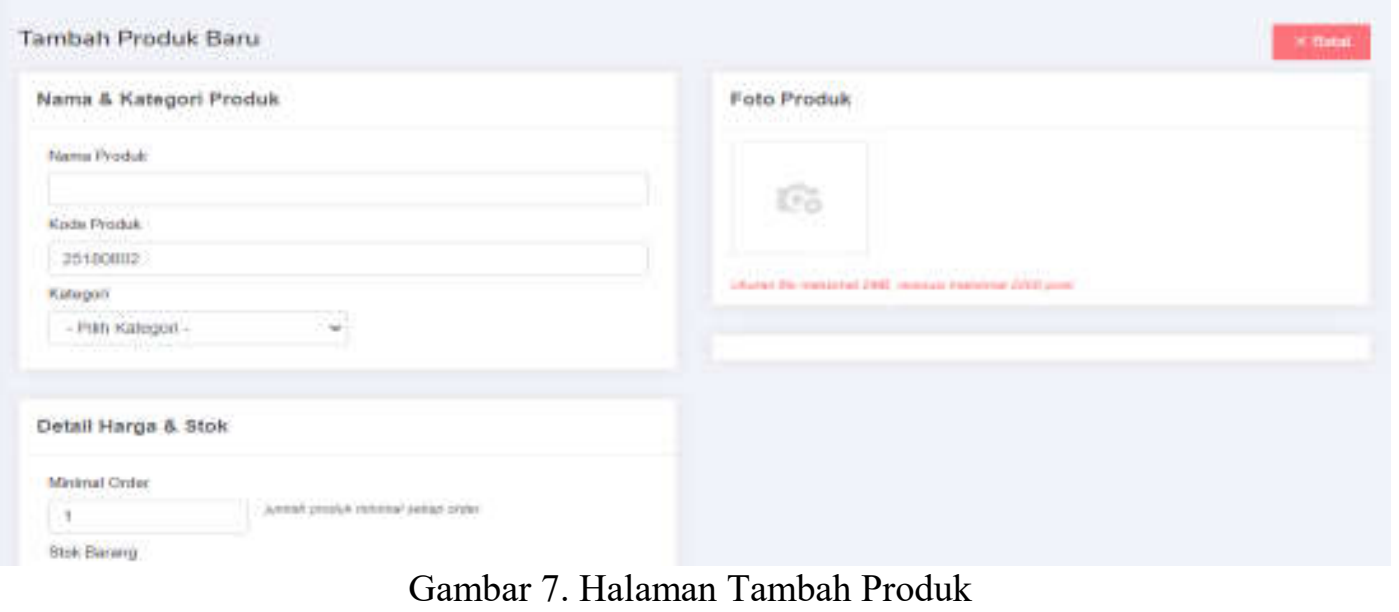

Gambar 7 Pada halaman produk di pojok kanan atas klik tombol tambah produk. Halaman tambah produk digunakan untuk menambahkan produk baru pada sistem informasi higaragro. Masukan nama produk, kode produk, pilih katergori produk, isikan detail harga, stok, harga coret/promo, harga normal, berat produk, deskripsi produk secara lengkap dan tambahkan gambar produk kemudian klik tombol simpan untuk menyimpan produk, klik tombol reset untuk mengulangi pengisian produk dan batal untuk membatalkan penyimpanan produk baru.

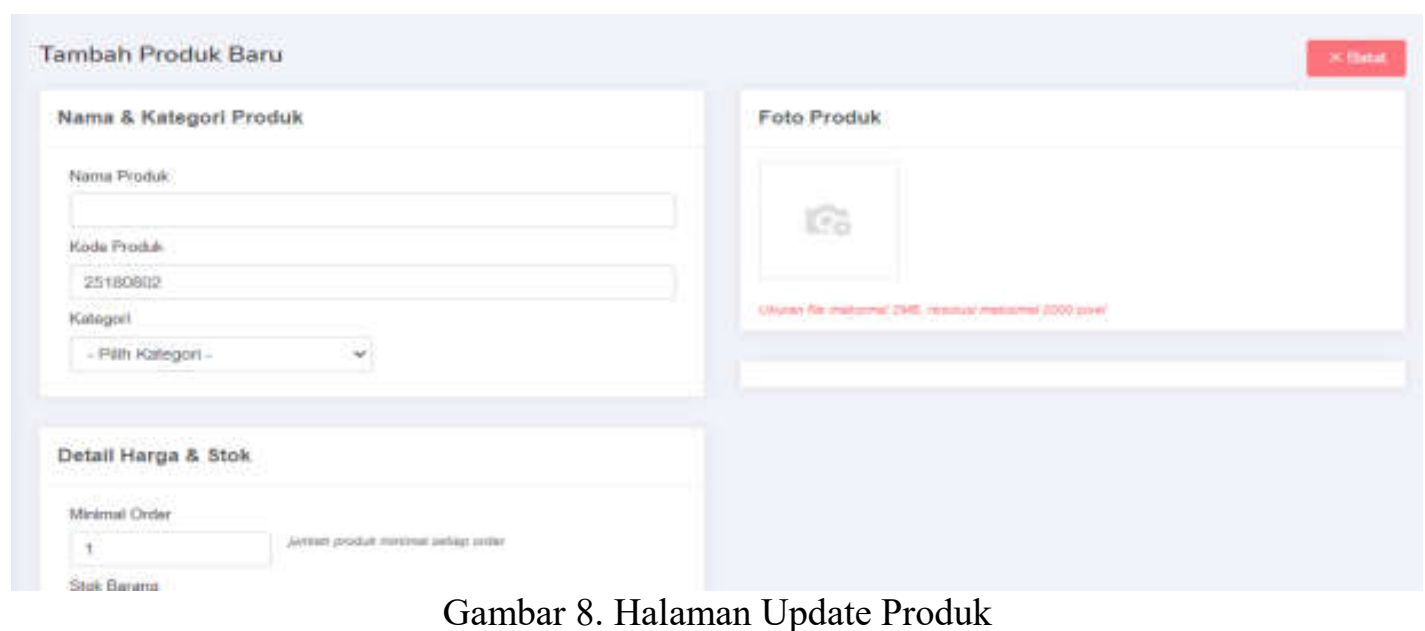

Gambar 8 Pada halaman produk tentukan produk yang ingin di update dan klik tombol biru bergambar pena untuk melakukan edit. Halaman edit produk digunakan untuk mengupdate produk lama pada sistem informasi higaragro. Masukan nama produk, kode produk, pilih katergori produk, isikan detail harga, stok, harga coret/promo, harga normal, berat produk, deskripsi produk secara lengkap dan tambahkan gambar produk kemudian klik tombol simpan untuk menyimpan produk, klik tombol reset untuk mengulangi dan batal untuk membatalkan. 


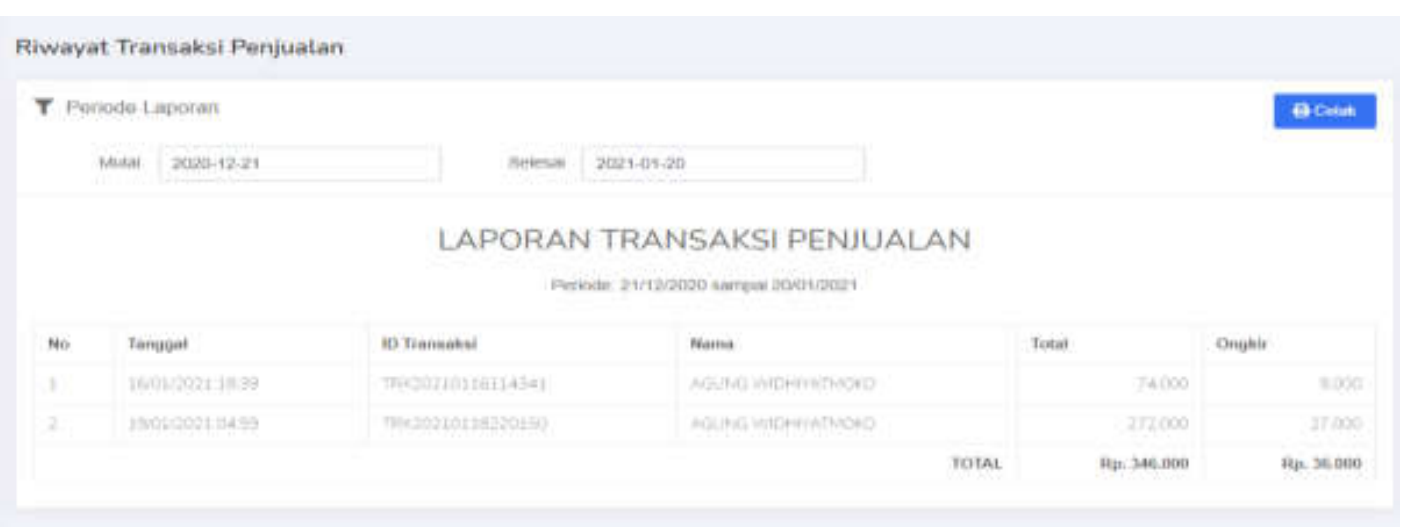

Gambar 9. Tampilan Laporan Penjualan

Gambar 9 Klik menu laporan penjualan pada halaman utama admin untuk masuk ke halaman laporan penjualan. Halaman laporan penjualan menampilkan riwayat transaksi penjualan yang terjadi pada aplikasi higaragro.com. Menampilkan laporan penjualan dapat difilter berdasarkan tanggal transaksi penjualan menyesuaikan periode laporan penjualan yang ingin ditampilkan.

\section{KESIMPULAN}

Berdasarkan penelitian yang telah dilakukan pada Toko Bibit Tanaman Higar Agro mengenai sistem informasi penjualan bibit tanaman di toko higar agro berbasis android, dapat diambil kesimpulan bahwa sistem informasi penjualan bibit tanaman di toko Higar agro berbasis android disusun menggunakan analisa PIECES untuk mengoreksi dan memperbaiki sistem lama yang sedang berjalan dalam hal ini penulis berhasil memperbaiki tertundanya pemrosesan pesanan karena antrian dari pesanan yang sebelumnya dan berhasil menampilkan informasi yang lebih baik kepada calon customer. Sistem informasi penjualan yang diterapkan pada toko bibit tanaman Higar Agro dalam hal pembangunan sistem dirancang dan digambarkan menggunakan flowchart, Unified Modelling Language, use case diagram, class diagram activity diagram dan squence diagram sehingga memudahkan penulis menganalisa sistem yang dibangun. Sistem informasi penjualan bibit tanaman di toko Higar agro berbasis android dikembangkan dengan sistem admin berbasis web yang dibuat menggunakan bahasa pemrograman PHP, HTML dan Code Igniter sehingga sistem informasi yang dibangun dapat dengan mudah di aplikasikan secara online. Berdasarkan implementasi sistem informasi penjualan bibit tanaman di toko Higar agro berbasis android peneliti menyimpulkan bahwa telah berhasil membangun sistem informasi yang lebih baik untuk memudahkan customer dalam pencarian informasi dan memudahkan admin dalam proses penjualan hingga pembuatan laporan penjualan.

\section{SARAN}

Sistem Informasi Penjualan Bibit Tanaman di Toko Higar Agro Berbasis Android, masih dapat dikembangkan oleh peneliti berikutnya lebih lanjut, antara lain menambahkan notifikasi order via whatsapp sehingga admin dapat melihat dengan mudah adanya orderan masuk. Menambahkan notifikasi pengiriman via whatsapp, sehingga customer dapat dengan mudah mengetahui produk yang dibeli sudah diproses pengiriman. Pemesanan produk sebaiknya dapat menggunakan metode pre-order. Pembuatan grafik pembelian berdasarkan lokasi. Menambahkan lokasi dan alamat took serta laporan customer atau user.

\section{DAFTAR PUSTAKA}

[1] Andri, K. (2003). Perancangan Sistem Informasi. Yogyakarta: Gava Media.

[2] Hidayatullah Priyanto, J. K. (2014). Pemrograman WEB. Bandung: Informatika 
Bandung.

[3] Jogiyanto, H. (2005). Analisa dan Desain Sistem Informasi: Pendekatan Terstruktur Teori dan Praktik Aplikasi Bisnis. Yogyakarta: ANDI.

[4] Loveri, T. (2017). Sistem Informasi Penyaluran Benih Dinas Pertanian Tanaman Pangan Holtikultura Kabupaten Pasaman Barat. Jurnal Ilmu Komputer Vol 6.1 , 33-39.

[5] Moekijat. (2000). Manajemen pemasaran. Bandung: Mandar maju.

[6] Munir. (2013). MULTIMEDIA dan Konsep Aplikasi Dalam Pendidikan. Bandung: Alfabeta.

[7] Pressman, R. S. (2001). Software Engineering: A Practitioner's Approach. Fifth Ed. New York: McGraw-Hill Book Company.

[8] Safaat, N. h. (2012). Pemrograman Aplikasi Mobile Smartphone dan Tablet PC berbasis android, Cetakan Pertama, Edisi Revisi. Bandung: Informatika Bandung. 